NBSIR 77-1388

\section{A NEW LOOK AT WINDOWS}

Belinda L. Collins

Rosalie T. Ruegg

Robert Chapman

Tamami Kusuda

Center for Building Technology Institute for Applied Technology

National Bureau of Standards

Washington, D.C. 20234

January 1978

U.S. DEPARTMENT OF COMMERCE, Juanita M. Kreps, Secretary

Dr. Sidney Harman, Under Secretary

Jordan J. Baruch, Assistant Secretary for Science and Technology

NATIONAL BUREAU OF STANDARDS, Ernest Ambler, Acting Director 


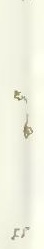




TABLE OF CONTENTS

Page

1.0 Introduction $\quad 1$

2.0 Key Factors Affecting Window Thermal Performance 3

2.1 Size 3

2.2 Orientation/Shading 4

2.3 Thermal Resistance and Air Leakage 6

2.4 Management of Interior Window Coverings 7

2.5 Daylighting 8

3.0 Case Example $\quad 8$

3.1 Approach 9

3.2 Energy Costs 12

3.2.1 First Level of Analysis - Thermal Loads 12

3.2.2 Second Level of Analysis - Management of Windows 15

3.2.3 Third Level of Analysis - Daylighting and Management $\quad 16$

3. 3 Acquisition Costs 20

3.4 Maintenance and Repair Costs 20

3.5 Life-Cycle Costs 24

$\begin{array}{lll}4.0 & \text { Conclusions } & 30\end{array}$

References $\quad 32$ 
K: 
Fig. 1. Effect of Changing Sun Position on the Shading of South-Facing Windows

Fig. 2. Schenatic Diagram of House with Residential Module Shown in Shaded Areas

Fig. 3. Estimated Yearly Energy Costs with North (N) or South (S) Facing Window with Gas or Electric (Elec) Heat: Analysis of Internal and External Thermal Loads Only

Fig. 4. Estimated Yearly Costs with North (N) or South (S) Facing Window with Gas or Electric (Elec) Heat: Analysis of Internal and External Loads, Window Management and Nighttime Thermostat Adjustment

Fig. 5. Estimated Yearly Energy Costs with North (N) or South (S) Facing Window with Gas or Electric (Elec) Heat: Analysis of Internal and External Loads, Management, Adjustment, and Daylight

Fig. 6. Savings or Losses Due to a Single-Glazed, South-Facing Window over 25 Years for a Residential Module with Gas Heating and Electric Cooling - Washington, D.C. Case Example

Fig. 7. Savings or Losses Due to a Double-Glazed, South-Facing Window over 25 Years for a Residential Module with Gas Heating and Electric Cooling - Washington, D.C. Case Example

Fig. 8. Savings or Losses Due to a Single-Glazed, North-Facing Window over 25 Years for a Residential Module with Gas Heating and Electric Cooling - Washington, D.C. Case Example

Fig. 9. Savings or Losses Due to a Double-Glazed, North-Facing Window over 25 Years for a Residential Module with Gas Heating and Electric Cooling - Washington, D.C. Case Example 


\section{LIST OF TABLES}

Page

1. Assumptions for Case Example

2. Acquisition Costs of a Window in Excess of the Cost of a Non-Windowed Wall

3. Cost of Window Accessorles

4. Maintenance and Repair Costs 


\begin{abstract}
Recent design recommendations have called for reduced window area in buildings to conserve energy. This report presents new information on thermal loads, daylighting, management, and life-cycle costs which indicates that such recommendations may neglect important design and operational aspects of windows which can conserve energy resources and reduce life-cycle building costs. A case example is described in which energy consumption and life-cycle costs are given for windows in a typical house in the Washington, D.C. area. Noticeable reductions in overall energy consumption and life-cycle costs are found if daylight is used, and if the window is managed. It is suggested that bullders and lending institutions consider the long-term effects of window design and operation decisions.
\end{abstract}

Key Words: Daylighting; energy conservation; life-cycle costs; residential; solar heat gain; window; window management 


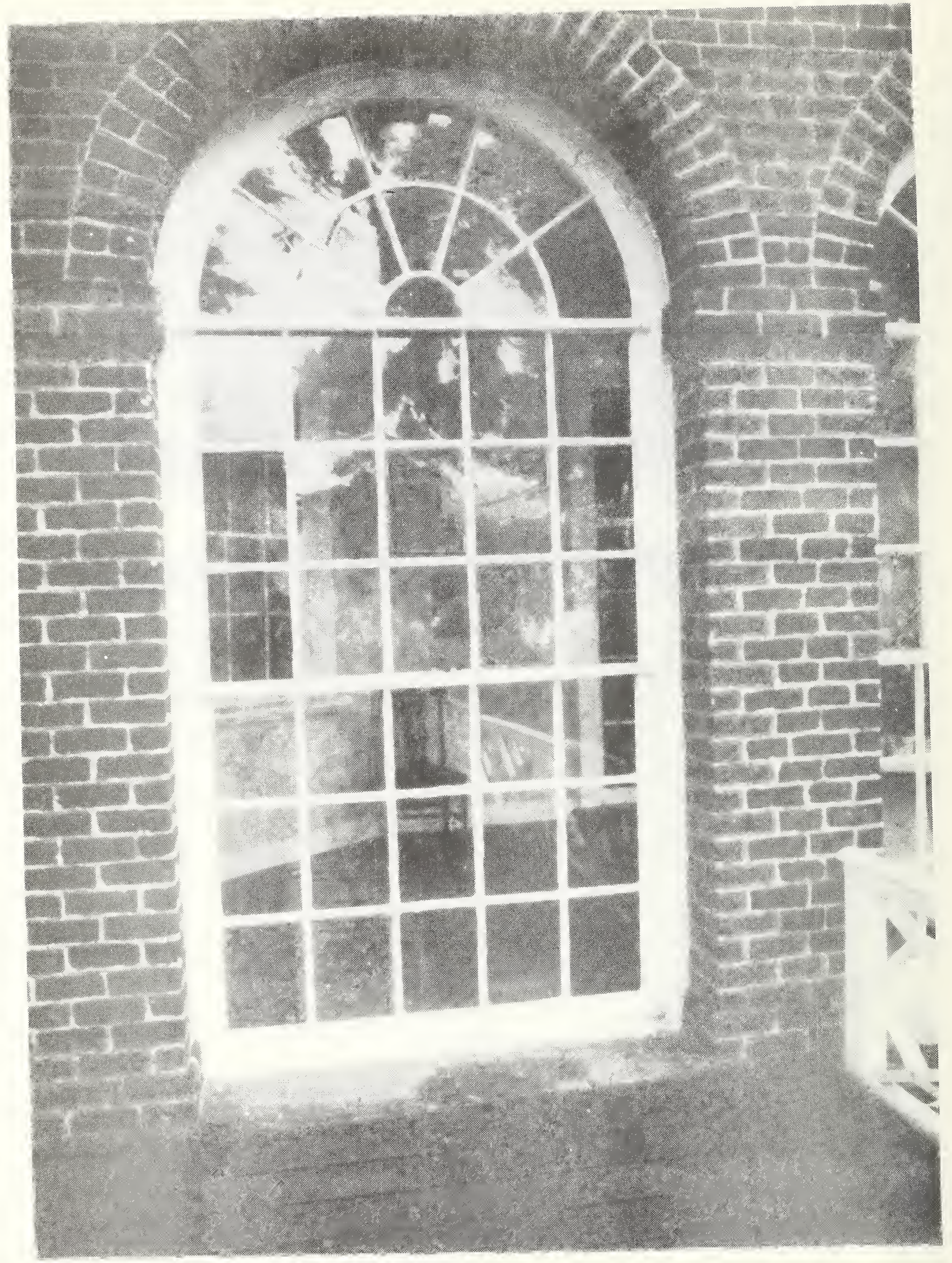




\section{A NEW LOOK AT WINDOWS}

\subsection{INTRODUCTION}

With rising fuel prices driving homeowners' utility bills to ever higher levels, builders, homeowners, and mortgage lenders are giving greater attention to overall monthly housing costs. Unexpectedly large utility bills can hurt the family budget and jeopardize repayment of the mortgage loan.

A considerable amount of energy waste in buildings has been attributed to windows. Their thermal resistance is typically lower than that of the surrounding wall; they leak air; and they let in the hot summer sun. Simple calculations of the thermal gains and losses attributed to windows have led to recommendations that window area be reduced drastically or that windows be eliminated where possible.

Such recommendations neglect, however, the many possible benefits that can be provided by windows -- benefits not only of view and aesthetics -- but also, potentially, of energy conservation. When windows are utilized as passive solar collectors, light sources, and ventilators, a different picture of their impact upon energy conservation emerges.

Depending upon critical decisions about design and use, windows can either greatly increase, decrease, or have little impact on energy consumption and total life-time building costs. The range of impacts is illustrated by the following highlights of a case study which measures the energy consequences associated with windows of different design, orientation, and use in a "typical" Washington, D.C. home. 
- Poorly designed and operated windows often account for as much as 25 percent of typical energy use.

- Yearly energy costs can skyrocket as window sizes increase if the windows are poorly designed and operated.

- When carefu11y located and operated, windows -- even large windows -- can be energy efficient.

- For a given level of annual energy use, a south-facing window can be almost twice as large as a north-facing window.

- Double glazing will reduce energy costs, but may not always be cost effective.

- Well designed windows and good operating practices can result in net savings to homeowners over the life of their house. This article is aimed at helping the building community and mortgage lenders determine the likely energy effects of windows in new housing and thereby encourage the choice of cost-effective windows. By choosing energy-efficient and cost-effective window designs, the building community can reduce the impact of rising utility costs while serving the national interest for conserving nonrenewable energy resources.

The information in this article is drawn from an investigation of window performance in residences and in office buildings at the National Bureau of Standards (NBS). The NBS research team first identified specific window design strategies with the potential for saving energy (1). A computer model was then developed to estimate the impact of selected window strategies on energy conservation (2). Life-cycle costing techniques were used to account for the costs of acquisition, 
maintenance, repair, and energy, to determine the overall costs of alternative window designs over the life of the building (3). The benefits of windows to people in buildings (in terms of view and aesthetics) were also investigated (4).

The NBS research effort was sponsored jointly by NBS, the Energy Research and Development Administration (ERDA), and the Department of Housing and Urban Development (HUD). The study was undertaken in response to the needs of the building community for reliable information on window performance. It is a step in the process of formulating new building standards and design recommendations for windows.

Some of the key factors affecting the thermal performance of windows are first described briefly. Then the energy and cost impacts of particular window designs in a typical residence in the Washington, D.C. area are shown.

\subsection{KEY FACTORS AFFECTING WINDOW THERMAL PERFORMANCE}

In addition to climate, there are a number of basic design and operational factors which are critical to a window's performance. These include: size, orientation and exterior shading, thermal resistance, air leakage, use of internal and external window coverings, and use of daylight.

\section{$2.1 \underline{\text { SIZE }}$}

Decisions about the size of a window can often pose a dilemma for designers, builders and owners. Calculations of the increase in thermal loads associated with increasing window area have led to recommendations that window area be as small as possible, often as small as 5 to 8 percent of the window wall. Calculations of only the thermal loads may 
may not consider potential benefits which also tend to increase as window size increases. These benefits include usable solar collection during the heating season, ventilation during the cooling season, and daylight. In addition, thermal calculations do not always include the potential for reducing negative thermal effects by shading and insulating the window area. Furthermore, the varied thermal effects associated with different window orientations and glazing types are often overlooked. Thus, to determine the optimal window size for conserving energy, both negative and positive thermal effects must be considered.

\subsection{ORIENTATION/SHADING}

A window's orientation plays a critical role in determining the balance between desirable and undesirable thermal effects. In moderate to cold climate zones, the annual energy costs of south-facing windows are generally lower than those for northern, eastern or western exposures. Their energy costs are reduced because the elevation of the sun is lowest during the winter so that south-facing windows receive more direct sunlight. During the summer, the elevation of the sun is higher, so that south-facing windows receive less direct sunlight. Furthermore, as Figure 1 indicates, the changing elevation of the sun permits permanent overhangs to be installed which shade south-facing windows during the summer, but not during the winter. 

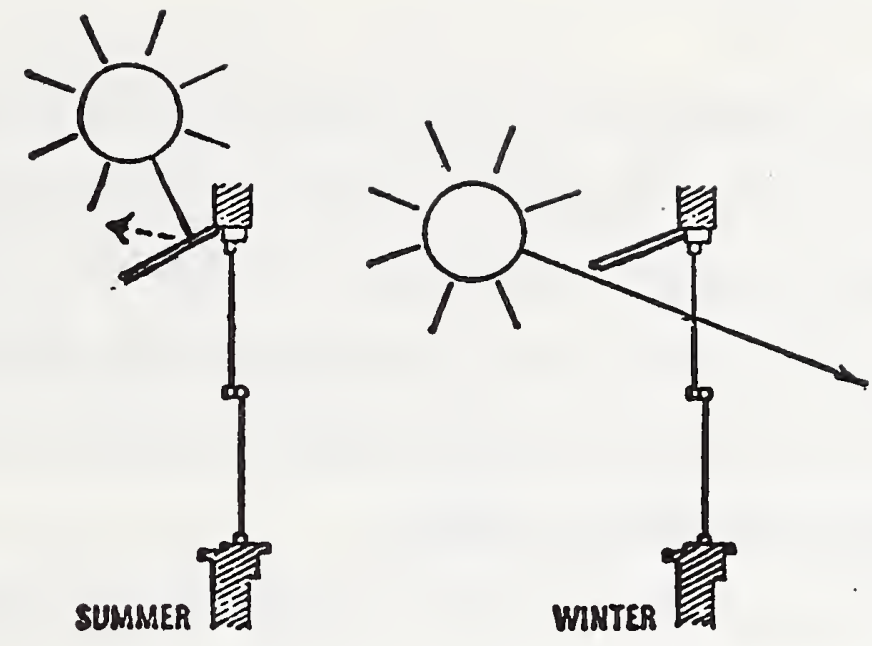

\section{Figure 1. Effect of Changing Sun Position on the Shading of South-Facing Windows}

On the other hand, because windows oriented in a northerly direction receive little solar heat gain, their net heat loss is greater than that of other exposures during the winter. This heat loss is sometimes increased by prevailing northerly winds which further decrease a window's thermal resistance.

Windows with either eastern or western exposures also have considerable winter heat loss. In addition, they have greater heat gains in the summer because they are difficult to shade against the lower summer sun. Thus, the energy consumption due to east or west-facing windows is often greater than that for south-facing windows.

Given a fixed, but undesirable, window orientation, unwanted solar heat gains can be reduced by the use of shading devices which block the direct rays of the sun. Shading devices are most effective if they are located outside of the window, because they will block the sun's heat before it reaches the interior of the house. Roof overhangs, awnings, 
sun screens, vegetation, and operable shutters are examples of effective exterior shading devices.

Orientation influences the type of shading device selected. For a southern exposure, horizontal devices are most effective because the sun is high in the sky during the summer. For eastern or western exposures, vertical fins or lattice-type devices are most effective because the sun is lower in the sky and moves diagonally across the window.

\subsection{THERMAL RESISTANCE AND AIR LEAKAGE}

Probably the most common method for improving the thermal performance of windows is to increase their resistance to heat loss. Thermal resistance may be increased either by adding storm windows, plastic sheets, draperies, shutters, or by installing special glazing products such as sealed insulating glass. Storm windows are now marketed as permanent, operable fixtures, which can either be installed on new houses during construction or added to existing houses. Sealed insulating glass, on the other hand, is used mainly in new residential construction. In addition to reducing heat loss, storm windows or insulating glass can reduce water vapor condensation, radiant heat loss, and air leakage.

The cost effectiveness of double glazing depends largely on the severity of the climate, the cost and availability of heating fuel, and the size and orientation of the window. For example, in a moderate climate, double glazing usually will reduce energy costs only slightly for south-facing windows, and may, therefore, not be cost effective. On the other hand, double glazing is usually an effective treatment for north-facing windows (in a moderate climate) because it reduces energy 
costs substantially. Yet, in a severe climate, double or triple glazing may be cost effective for all orientations.

Upgrading the thermal resistance of a window can save significant amounts of energy through reduced conductance, but energy can still be wasted through air leakage (infiltration) around the window. Infiltration may occur around the operable portions of the window or between the window frame and the wall. Alr leakage increases with the external wind speed and the inside-outside temperature difference. These losses can be reduced by the installation of weatherstripping and good latching hardware or by caulking and insulating the frame-wall gap. Caulking and weatherstripping are particularly cost effective since they are relatively inexpensive, entail low labor cost, and usually provide a noticeable reduction in heating costs.

\subsection{MANAGEMENT OF INTERIOR WINDOW COVERINGS}

Although double glazing and fixed shading can reduce winter heating and summer cooling costs substantially, they are not readily adaptable to changing environmental conditions. Window performance can be improved further by the selective adjustment of shading devices and thermal barriers -- hereafter referred to as "window management". For example, venetian blinds, draperies, or shutters may be closed by the homeowner to block solar radiation during the summer, but opened to admit solar heat during the winter. Thermal barriers may also be used to reduce the heat flow from the house on cold winter nights. At the same time, these window coverings can be used by the homeowner to provide additional benefits unrelated to energy use -- e.g., to control glare, reduce outside distractions, provide greater privacy, and to complement 
the interior decor of the home.

\subsection{DAYLIGHTING}

One of the best means for improving the performance of windows is to use them to provide natural light instead of electric light during the day. Most private residences in the United States are lighted by incandescent lights, a relatively inefficient light source which generates a considerable amount of heat. The substitution of daylight for incandescent lighting will not only reduce the cooling requirements within the room but will also cut down on the amount of electricity used for lighting. Potential savings from daylight may not be as great in the winter because the heat from the electric lights can help to heat the room. Nevertheless, because of the potential for saving energy by using daylight, it may not be energy efficient to exclude a window from a room which will receive substantial use during the day.

A moderately-sized window can provide adequate daylight up to about 10 to 15 feet into the room under all but the cloudiest conditions (2). At distances beyond this, supplementary task 1ighting is generally required. Careful consideration of both window location and size can improve the effectiveness of daylighting as the primary light source. For instance, tall vertical windows permit daylight to penetrate a greater distance into a room than narrow horizontal windows. Similarly, windows placed high on the wall permit more daylight to enter. Skylights can also be effective for daylighting (5).

\subsection{CASE EXAMPLE}

Now let us examine in dollar terms the impact that each of these factors can have upon yearly energy costs and total life-cycle costs. 
We will concentrate upon one example in a single location to illustrate the range of possibilities for altering the energy balance at the window.

This case study is intended to show, for a typical residence in the Washington, D.C. area, how various window sizes, orientations, thermostat adjustment, daylight, and window management affect not only annual energy costs but also lifetime building ownership costs. The costs of purchase, installation, maintenance, and repair are taken into account, as well as energy costs. Our focus is on the window of an $18^{\prime} \times 15^{\prime}$ room with one exterior wall in a typical brick veneer house. The room could be envisioned as the family room-kitchen of the house given in Figure 2. Additional assumptions are presented in Table 1.

\subsection{APPROACH}

In the case example, the yearly and lifetime energy costs associated with changes in size, orientation, thermal resistance, window management, and daylighting are calculated first. Next, the costs of purchase, installation, maintenance, and repair are added to the energy costs in a life-cycle cost analysis.

The life-cycle cost analysis includes all the relevant costs or savings, past, present, and future, and takes into account changing prices due both to inflation and to changing supply and demand factors. It also incorporates the concept of the "time value of money," i.e., a dollar today is worth more than a dollar in the future, apart from inflation. The life-cycle cost model enables different window designs to be considered in terms of their net impact on building and energy costs over a number of years. 

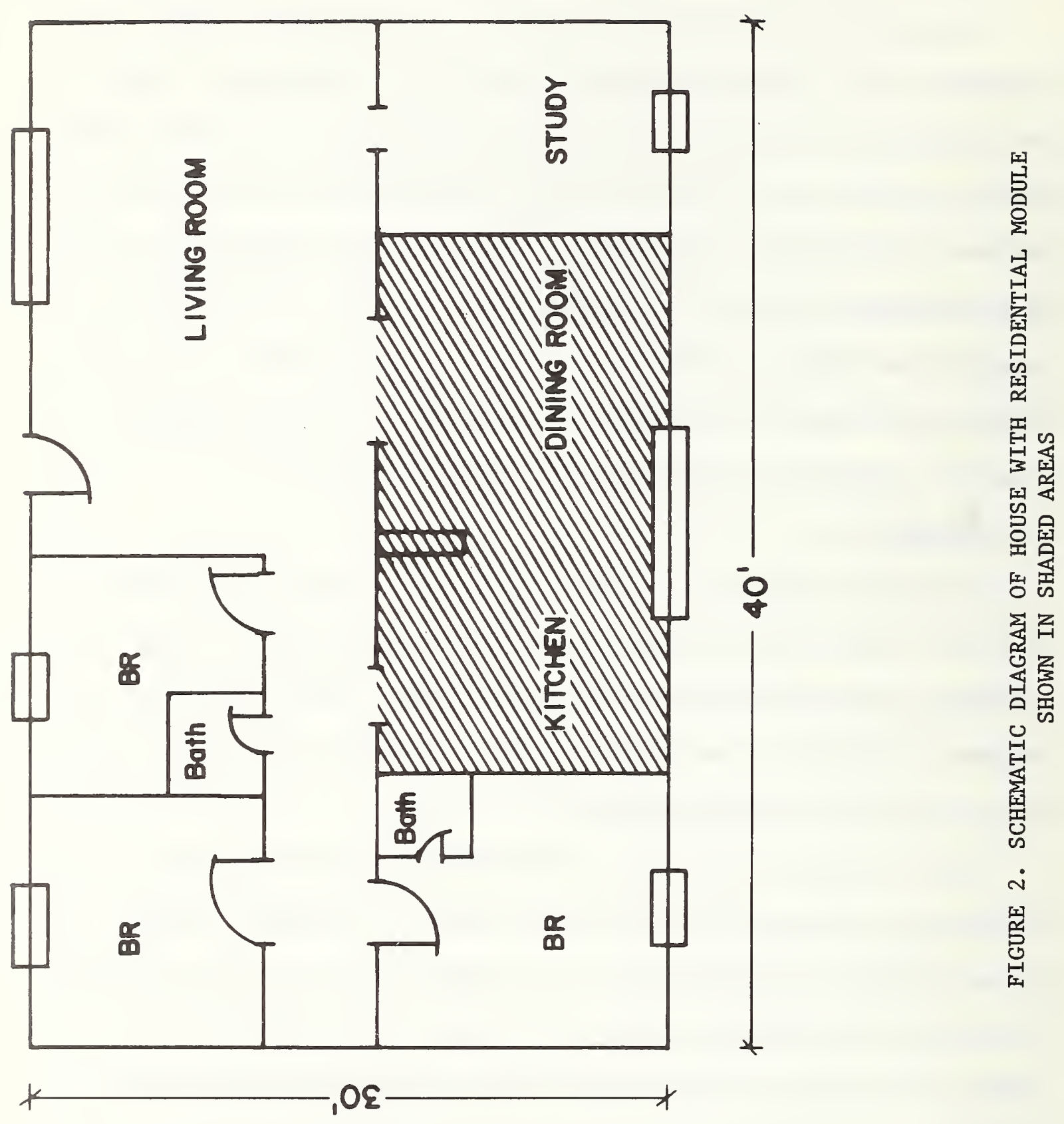
TABLE 1. ASSUMPTIONS FOR CASE EXAMPLE ${ }^{a}$

\begin{tabular}{|c|c|}
\hline Building Specifications & Assumptions \\
\hline $\begin{array}{l}\text { Dimensions of Module } \\
\text { Type of Construction } \\
\text { Exterior Wall Area } \\
\text { Window Size } \\
\text { Window Construction }\end{array}$ & $\begin{array}{l}18^{\prime} \text { wide } \times 15^{\prime} \text { long } \times 8^{\prime} \text { high } \\
\text { Block with brick veneer; u=0.07;3 } 1 / 2^{\prime \prime} \text { insul. } \\
144 \mathrm{sq} \text {. ft. } \\
0,12 \text {, } 18,30,60 \mathrm{sq} \text {. ft. } \\
\text { Wood; double hung; weather stripped }\end{array}$ \\
\hline Internal Loads ${ }^{c}$ & Specifications \\
\hline $\begin{array}{l}\text { Lights } \\
\text { Equipment } \\
\text { Air Leakage } \\
\text { Occupancy } \\
\text { Btu/person }\end{array}$ & $\begin{array}{l}0.65 \text { watts } / \mathrm{sq} . \mathrm{ft} . \\
0.52 \text { watts } / \mathrm{sq} \text {. ft. } \\
0.5 \text { air changes/hour } \\
0.5 \text { persons } \\
260 \text { Btu/hour }\end{array}$ \\
\hline System Efficiency & Specifications \\
\hline $\begin{array}{l}\text { Boiler Efficiency } \\
\text { Cooling C.O.P. } \\
\text { Electric Heating }\end{array}$ & $\begin{array}{l}0.65 \\
2.0 \\
1.0\end{array}$ \\
\hline Fuel Type & Costs \\
\hline $\begin{array}{l}\text { Electricity } \\
\text { Gas }\end{array}$ & $\begin{array}{l}3 € \text { per } \mathrm{KwH} \\
30 € \text { per therm }\end{array}$ \\
\hline Operation & Conditions \\
\hline Thermostat Adjustment & $\begin{array}{l}72^{\circ} \text { to } 62^{\circ} \mathrm{F} \text { winter nights } \\
78^{\circ} \text { to } 84^{\circ} \mathrm{F} \text { summer nights }\end{array}$ \\
\hline Window Management & Times \\
\hline $\begin{array}{l}\text { Thermal Shutters } \\
\text { Venetian Blinds }\end{array}$ & $\begin{array}{l}\text { Winter nights } \\
\text { Summer days }\end{array}$ \\
\hline
\end{tabular}

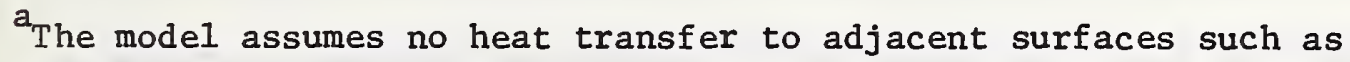
walls, floors, or ceilings.

bDue to the difficulty of modeling the thermal exchange between rooms, only a single room was modeled. Study of a single room within a larger house may not necessarily reflect the performance of the whole house.

${ }^{c}$ A11 loads are averaged over the 16 hour period from 7:00 AM to 11:00 PM. 
Each of the cost factors will be examined first separately. Then they will be combined into an overall life-cycle cost analysis.

\subsection{ENERGY COSTS}

A thermal model with three levels of analysis was developed to examine the effects on energy costs of varying window size, orientation, thermal resistance, management, and daylight utilization. The three levels of thermal analysis are presented here for north and south-facing windows of several sizes, and with single and double glazing.

In the first level of analysis, energy costs associated with a bare window are calculated, taking into account only the thermal loads. In the second, the calculation of energy costs includes thermal loads, but also allows for modifications in thermal loads by the selective use of thermostat adjustment and internal window coverings for shading and insulation ("window management"). In the third level, the computation of energy costs adds daylight utilization to window management and thermostat adjustment. Although the three levels of analysis simulate most of the important energy effects of windows, they are not fully comprehensive because they omit the potential savings or losses from natural ventilation.

For the three levels of analysis, energy costs are estimated for both gas and electric heating and for electric cooling. Energy costs also include the cost of electricity to operate the household equipment and interior lighting.

3.2.1 First Level of Analysis - Thermal Loads: First, we will consider how windows affect estimated yearly energy costs when only internal and external thermal loads are taken into account and the bare window is 
considered. This is the traditional approach taken in analyzing the influence of windows on energy consumption. It is the appropriate approach when neither daylighting nor management is feasible. In this analysis, the thermal gains and losses through the window wall are calculated for different window areas. In addition, thermal loads generated inside the room due to incandescent lighting, equipment, and human occupancy are estimated, along with the potential losses due to air infiltration.

Figure 3 shows the estimated yearly energy costs for the room as a function of the area of the window. Note that on the vertical axis, or zero window area, energy costs are given for a windowless room. To determine the operating costs attributable to just the window, the yearly operating costs for a room with a given window area must be subtracted from those for a windowless room with zero window area. Part A of Figure 3 demonstrates that, when only thermal loads are considered, estimated yearly energy costs increase for both northern and southern exposures as the size of the single-glazed window increases. A window with a northern exposure has greater energy costs, however, than one with a southern exposure, particularly when the more expensive electric heating is used. The added energy costs for the room are as much as $\$ 20$ to $\$ 25$ more per year for large window areas on the north wall with electric heat than for large windows on the south with gas heat.

Part B plots similar yearly energy costs for a room with a doubleglazed window. When double glazing is used, energy costs are lowered for both orientations. For example, double glazing lowers energy costs by about $\$ 30$ per year for the largest north-facing window in the 


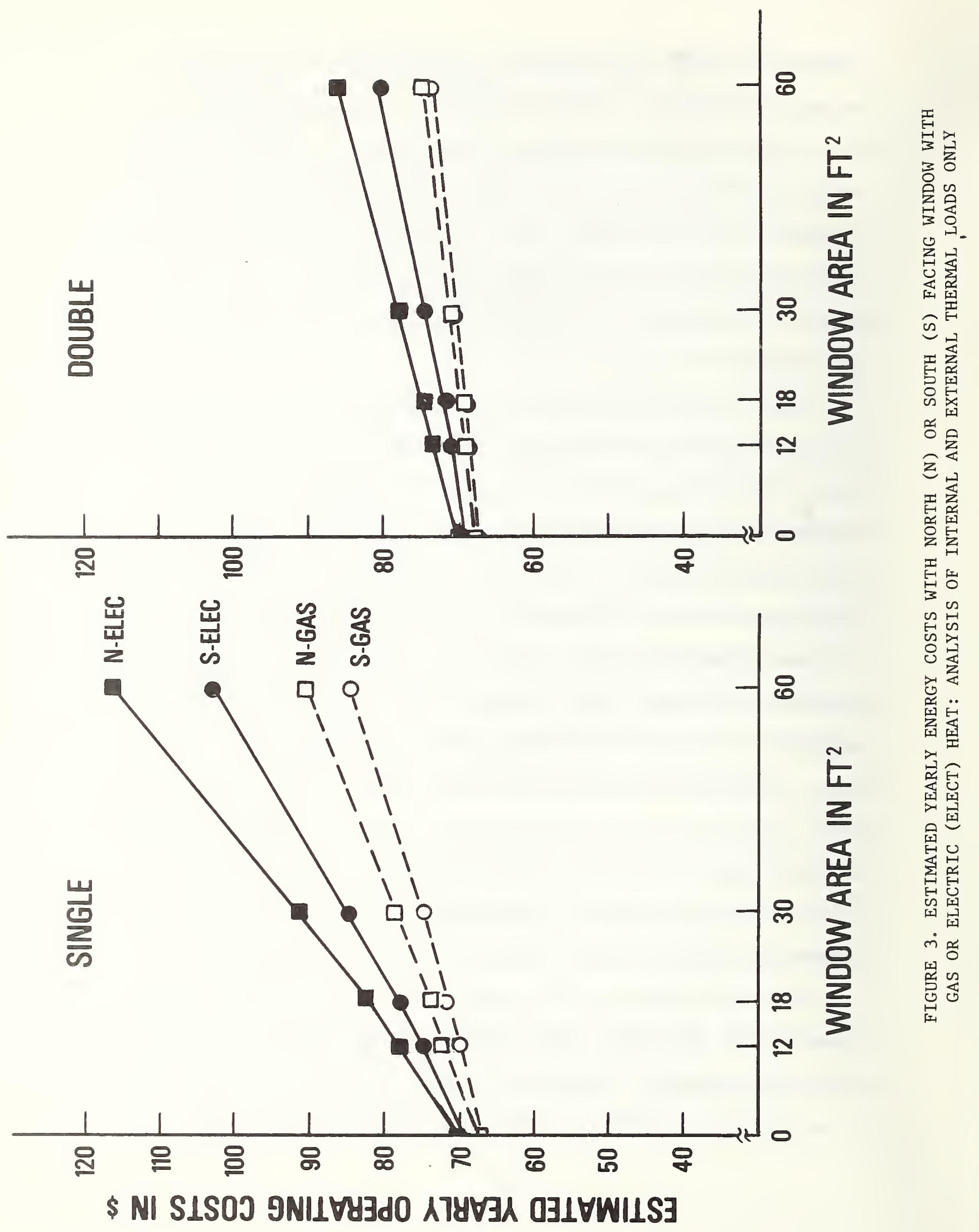


electrically heated room. The reduction is somewhat lower for the southfacing window.

To estimate the additional energy costs over the assumed 25 year life, it is necessary to take into account the cost of money (assumed here tc be 8 percent compounded annually) and the expected future rise in energy prices (assumed here to be in the range of 0 to 12 percent compounded annually). The adjusted yearly costs are then summed over the 25 years to estimate present value life-cycle energy costs. For example, the large area of single-glazed window on the north side, which adds about $\$ 24$ a year to the costs for gas heating and electric cooling, is expected to add between $\$ 250$ and $\$ 980$ to energy costs over 25 years, depending on the rate of increase in energy prices. The large area of double-glazed window on the south side, which adds about $\$ 6$ a year to costs for gas heating and electric cooling, is expected to add between $\$ 60$ and $\$ 250$ to energy costs over 25 years, depending on future prices. In summary, the first level of analysis has shown that increasing the size of a bare, unmanaged window in a room in a Washington, D.C. home will increase energy costs over those for a windowless room, even on the south side. The use of double glazing along with careful orientation of the window will reduce these costs, but they will still tend to rise with increasing window size.

\subsubsection{Second Level of Analysis - Management of Windows: In the second} level of analysis, the energy exchange at the window is assumed to be managed. In this example, wooden thermal shutters are used during winter nights and venetian blinds are used during summer days. In addition, the thermostat setting is reduced from $72^{\circ} \mathrm{F}$ to $62^{\circ} \mathrm{F}$ on winter 
nights and increased on summer nights from $78^{\circ} \mathrm{F}$ to $84^{\circ} \mathrm{F}$ (see Table 1 ). Figure 4, Parts $A$ and $B$, shows that management of the window and thermostat adjustment almost eliminate the negative thermal effect of increasing window area shown in Figure 3. (Thermostat adjustment reduces annual energy costs by about $\$ 5$, regardless of window area). For a managed, south-facing window, energy costs remain about level even if the window has single glazing. For the north-facing window, doubleglazing is needed to achieve the same effect.

Given that the yearly energy costs of a managed, south-facing window are negligible, the lifetime energy costs are also small. On the north side, the extra lifetime energy costs for a room with a singleglazed, managed window range from an insignificant amount to as high as $\$ 820$, depending upon both the size of the window and the present and future price of energy. With double glazing, the extra life-time energy costs of a north-facing window are held to no more than $\$ 200$.

\subsubsection{Third Level of Analysis - Daylighting and Management: In the}

third level of analysis, the effects of substituting daylight for electric light are added to the window management and load calculations. For this case example, it was assumed that the lights were turned off whenever daylight exceeded a specified level of illumination (see Table 1). Energy use was reduced for both lighting and cooling. The results of the daylighting analysis are more uncertain than those from the preceding two analyses. They are based upon a computer model which calculates the energy consequences of substituting natural light for electric 1ight, and which has not been adequately verified by laboratory and field testing. Furthermore, typical residential lighting 


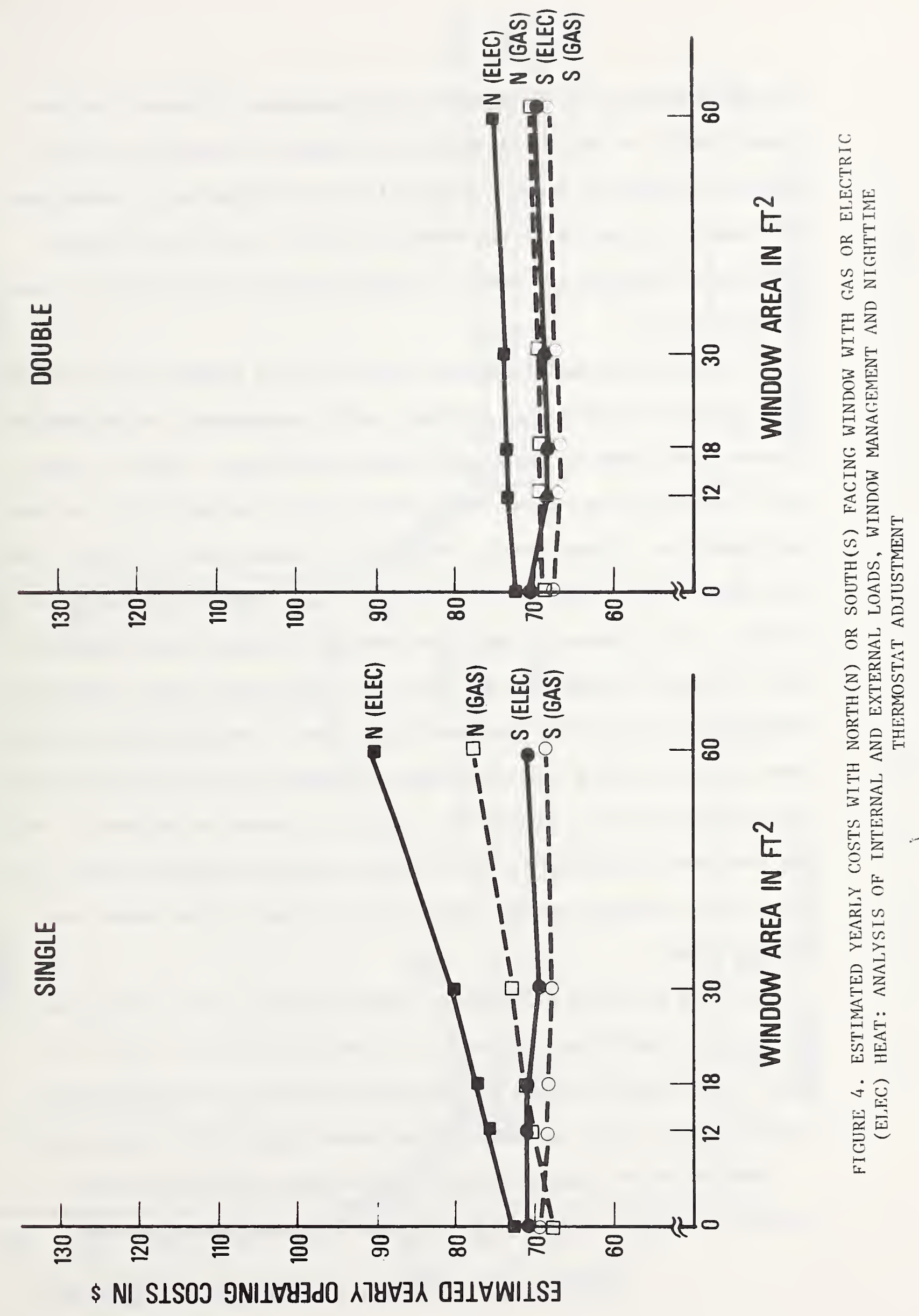


levels and patterns of use are not well documented. Although the calculated energy savings attributable to daylight are tentative, they do suggest that there is a large potential for some reduction of energy use. Experimental validation of the model is needed to reduce the present uncertainty regarding the amount of energy savings when daylight is used for illumination.

With the above qualifications in mind, let us examine the estimated energy costs of windows when daylight, window management, and thermostat adjustment are added to the thermal load calculations. Figure 5 shows that, when daylight is used, energy costs decline initially with increasing window area. These results contrast with those given in Figure 3 which shows energy costs continuously rising as window size is increased, and in Figure 4 which shows energy costs remaining constant with management. Part A of Figure 5 demonstrates that, for a gas-heated house, estimated yearly energy costs for a room with large areas of single glazing can be lower than those for a windowless room. Similar results occur when electric heating is used, provided the window is oriented to the south. Only when a window is oriented to the north and electric heating is used, are energy costs increased by the window, and then only if the window area is quite large.

As shown in Part B of Figure 5, double glazing is most effective when used on a north-facing window in a room with electric heat. For south-facing windows, double glazing has little effect on energy costs when gas heat is used, and only reduces costs slightly for electric heat. Translating the cost effects for the current year into lifetime savings and losses, we find that with rapidly rising energy prices, 


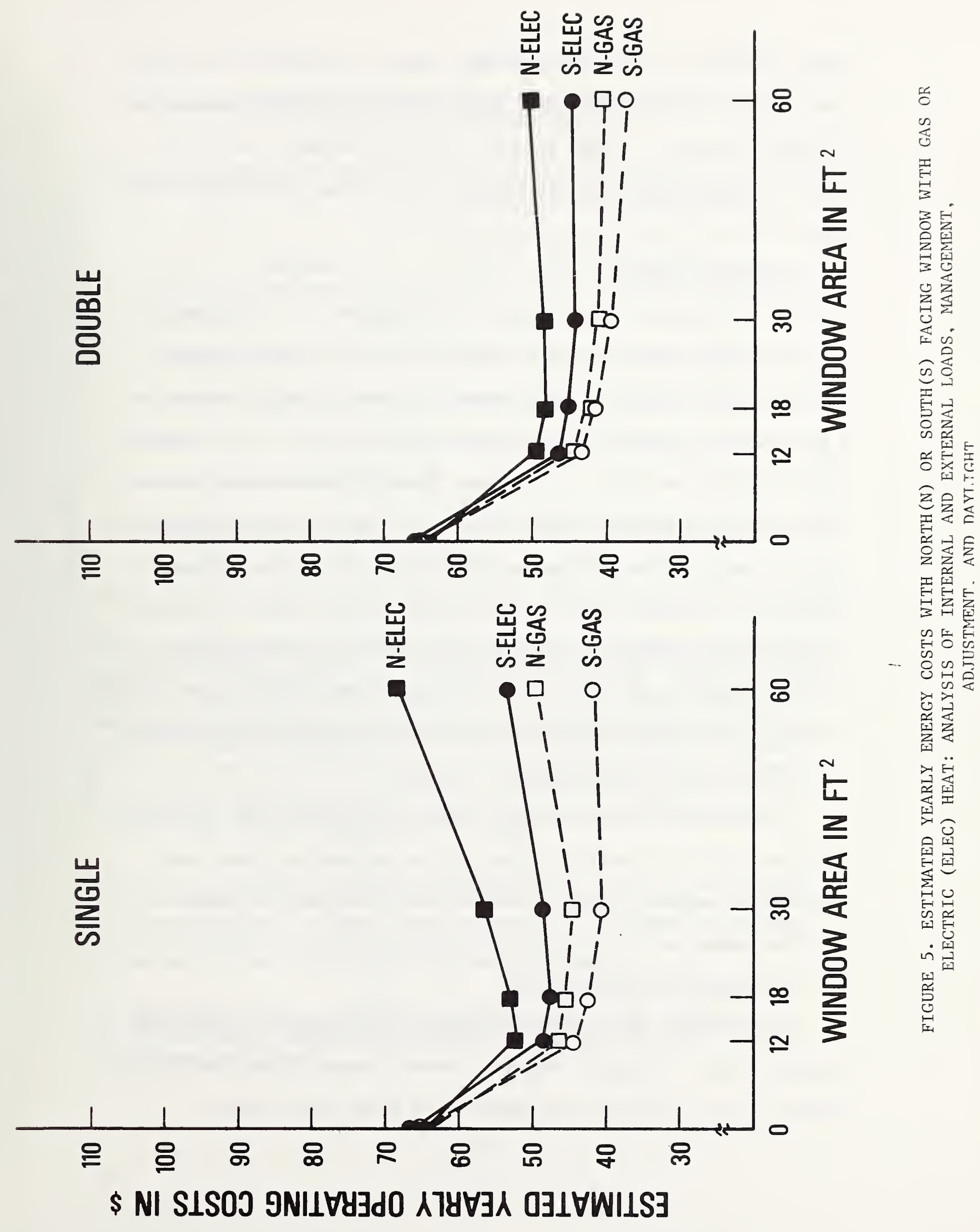


energy savings with a moderately-sized window are expected to be more than $\$ 1000$ over a 25 -year period if the window is properly managed and daylight is used. The only exception to this finding occurs with a large, single-glazed window on the north side of an electrically heated home.

\subsection{ACQUISITION COSTS}

Having calculated the energy costs associated with different window configurations, let us now turn to the costs of acquisition, maintenance, and repair. The purchase and installation of windows in a new home are generally more expensive than the costs of an equivalent area of nonwindowed wall. To estimate the additional acquisition costs, window costs are compared with wall costs in Table 2. This table shows that the costs of the purchase and installation of good quality wood windows are estimated to add between $\$ 18$ and $\$ 76$ to initial building costs for single-glazed windows, and $\$ 48$ to $\$ 216$ for double-glazed windows, depending on their size. (Because windows displace portions of the wall, they raise initial building costs by substantially less than their full purchase and installation costs.)

If management devices are used, additional acquisition costs are incurred. Costs of venetian blinds and wooden shutters based upon averages of currently quoted prices in the Washington, D.C. area are given in Table 3.

\subsection{MAINTENANCE AND REPAIR COSTS}

Window areas usually require somewhat more maintenance than nonwindowed areas. Estimated homeowner window cleaning costs, based on a current cost of $\$ .10 / \mathrm{ft}^{2}$, are shown in the first row of Table 4. 
Table 2

Acquisition Costs of a Window in Excess of the Cost of a Non-Windowed Wall

\begin{tabular}{|c|c|c|c|c|}
\hline \multirow[b]{2}{*}{ Component } & \multicolumn{4}{|c|}{ Dollar Costs, By Size of Area } \\
\hline & $12 f t^{2}$ & $18 \mathrm{ft}^{2}$ & $30 \mathrm{ft}{ }^{2}$ & $60 \mathrm{ft}^{2}$ \\
\hline \multicolumn{5}{|l|}{ Windows $^{a}$} \\
\hline Single Glazed & 52.20 & 70.70 & 122.55 & 245.10 \\
\hline Double Glazed & 81.80 & 109.36 & 192.61 & 385.23 \\
\hline Wa11 ${ }^{b}$ & 33.72 & 50.58 & 84.30 & 168.60 \\
\hline \multicolumn{5}{|c|}{ Window Cost Less Wal1 Cost ${ }^{c}$} \\
\hline Single Glazed & 18.48 & 20.12 & 38.25 & 76.50 \\
\hline Double Glazed & 48.08 & 58.78 & 108.31 & 216.63 \\
\hline
\end{tabular}

a Purchase prices are list retail prices, reduced 10 percent to reflect a typical builder's discount, for good quality wood double-hung windows, provided by a distributor in the Washington, D.C. area. Prices are for single and multiple units of windows of a size which comes close to providing ${ }_{2}$ the designated percentages of the exterfor wall in glazing. The $12 \mathrm{ft}^{2}$ area is provided by ${ }^{\mathrm{a}} 3^{\prime} \mathrm{x} 3^{\prime} 11^{\prime \prime}$ window; the $18 \mathrm{ft}^{2}$ area, by a $3^{\prime} \times 6^{\prime}$ window; the $30 \mathrm{ft}^{2}$ area by two $3^{\prime} \times 5^{\prime}$ windows, and the $60 \mathrm{ft}^{2}$ area, by four $3^{\prime} \times 5^{\prime}$ windows. An installation cost of $\$ 5.00$ per window or pair of windows is used, based on an estimate given by a home builder in the Washington, D.C. area.

${ }^{b}$ Costs of non-windowed wall areas corresponding in size to the windowed areas are based on a price of $\$ 2.81 / \mathrm{ft}^{2}$ as estimated by a home builder in the Washington, D.C. area. The wall section is assumed to be face brick veneer over 8 " cinder block with bullding paper sheathing, $31 / 2$ " of insulation, and $1 / 2^{\prime \prime}$ of painted interior drywall.

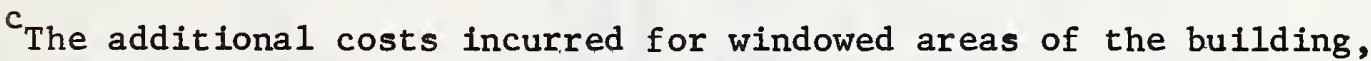
are the difference between the costs of windows and the costs of walls for the same wall area. 


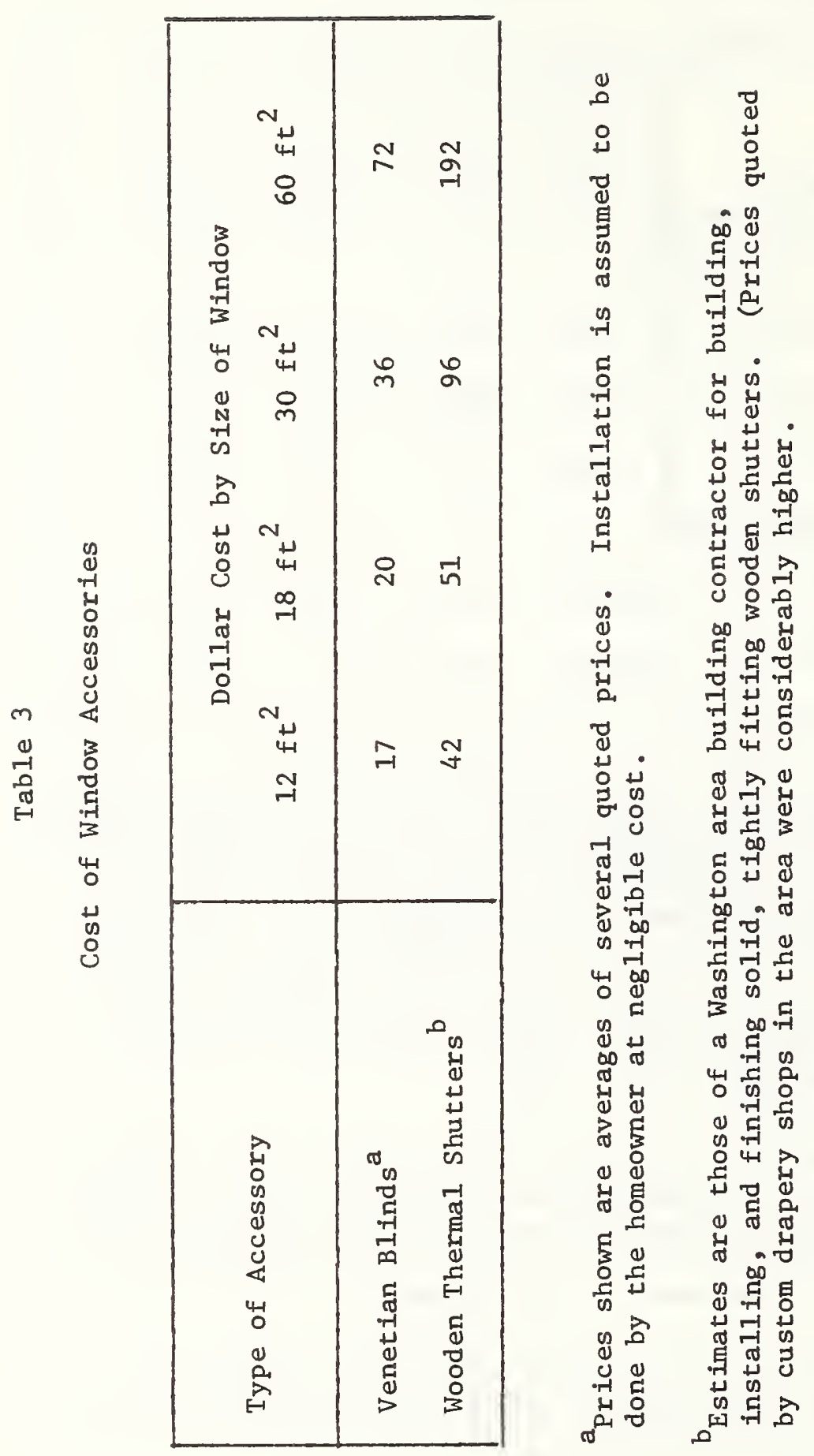




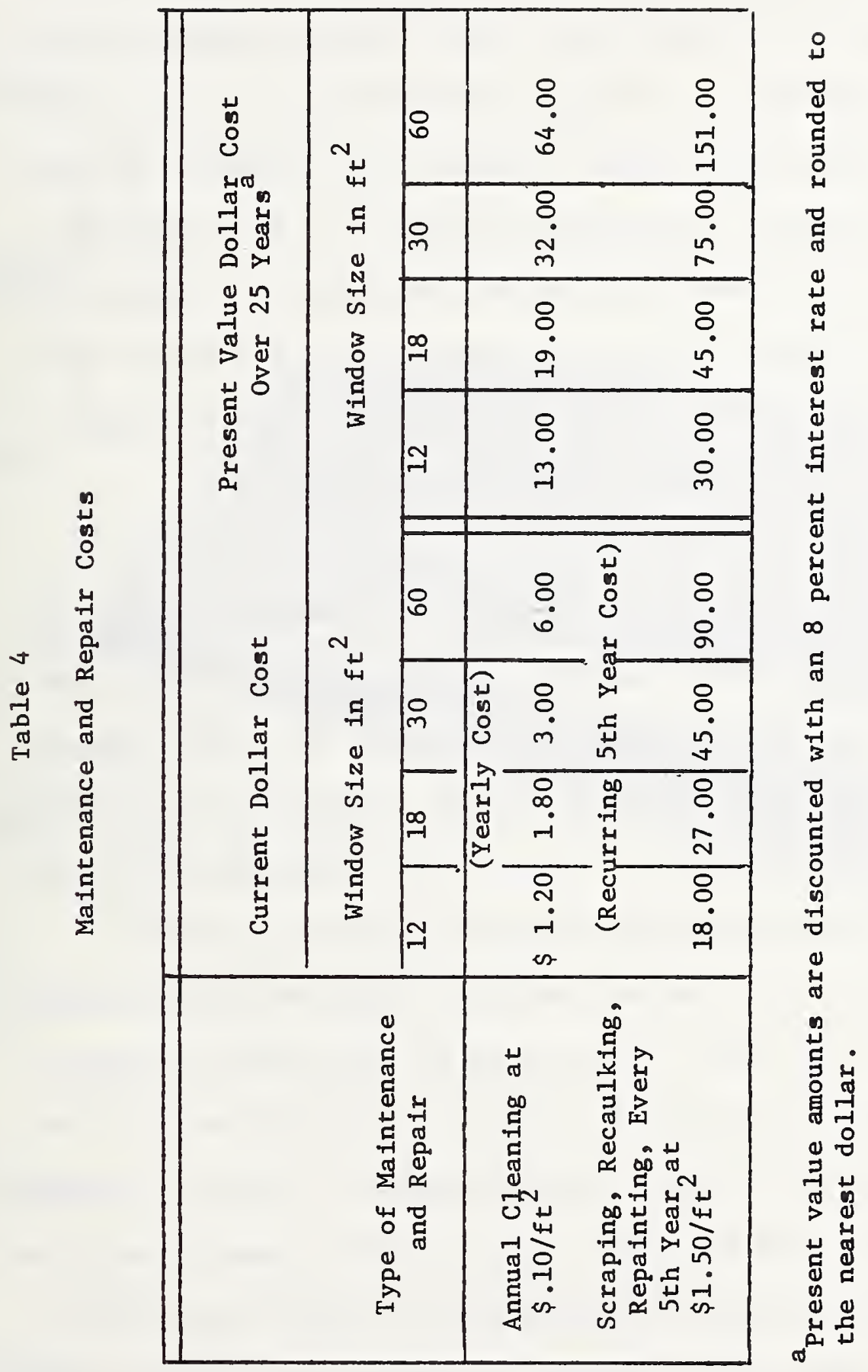


Estimates of maintenance and repair costs based on scraping, repainting, and recaulking once every five years at a current cost of $\$ 1.50 / \mathrm{ft}^{2}$, are shown in the second row of Table 4(6). Both costs are shown first in current dollars, and then, in the right hand portion of the table, in equivalent life-time present values. Present value estimates are based on future price increases in materials and labor at a rate comparable to the average of other goods and services, and based on an opportunity cost of money of 8 percent compounded annually. An estimate for window breakage is not included. The initially installed window is assumed to last the life of the building (estimated at 25 years).

\subsection{LIFE-CYCLE COSTS}

After considering each major cost element -- energy, purchase and installation of windows and accessories, maintenance, and repair -- we need to combine them over the life of the building for a more complete picture of the overall cost impact of windows. Life-cycle cost effects are shown in Figures 6 through 9. Figures 6 and 7 show the 1ife-cycle costs for single and double-glazed windows oriented to the south. Similarly, Figures 8 and 9 show the costs for single and double-glazed windows oriented to the north. Costs given in each figure are based on the use of gas heating and electric cooling. On each figure the three bands indicate the three levels of energy analysis: 1oad only, management, and management plus daylight. For each band, a range of potential net savings or losses is shown depending upon the future rate of fuel price escalation. This rate is assumed to range from 0 percent to 12 percent, as indicated by the extremes of the bands. 
FIGURE 6. SAVINGS OR LOSSES DUE TO A SINGLE-GLAZED, SOUTH-FACING WINDOW OVER 25 YEARS FOR

A RESIDENTIAL MODULE WITH GAS HEATING AND ELECTRIC COOLING - WASHINGTON,D.C. CASE EXAMPLE

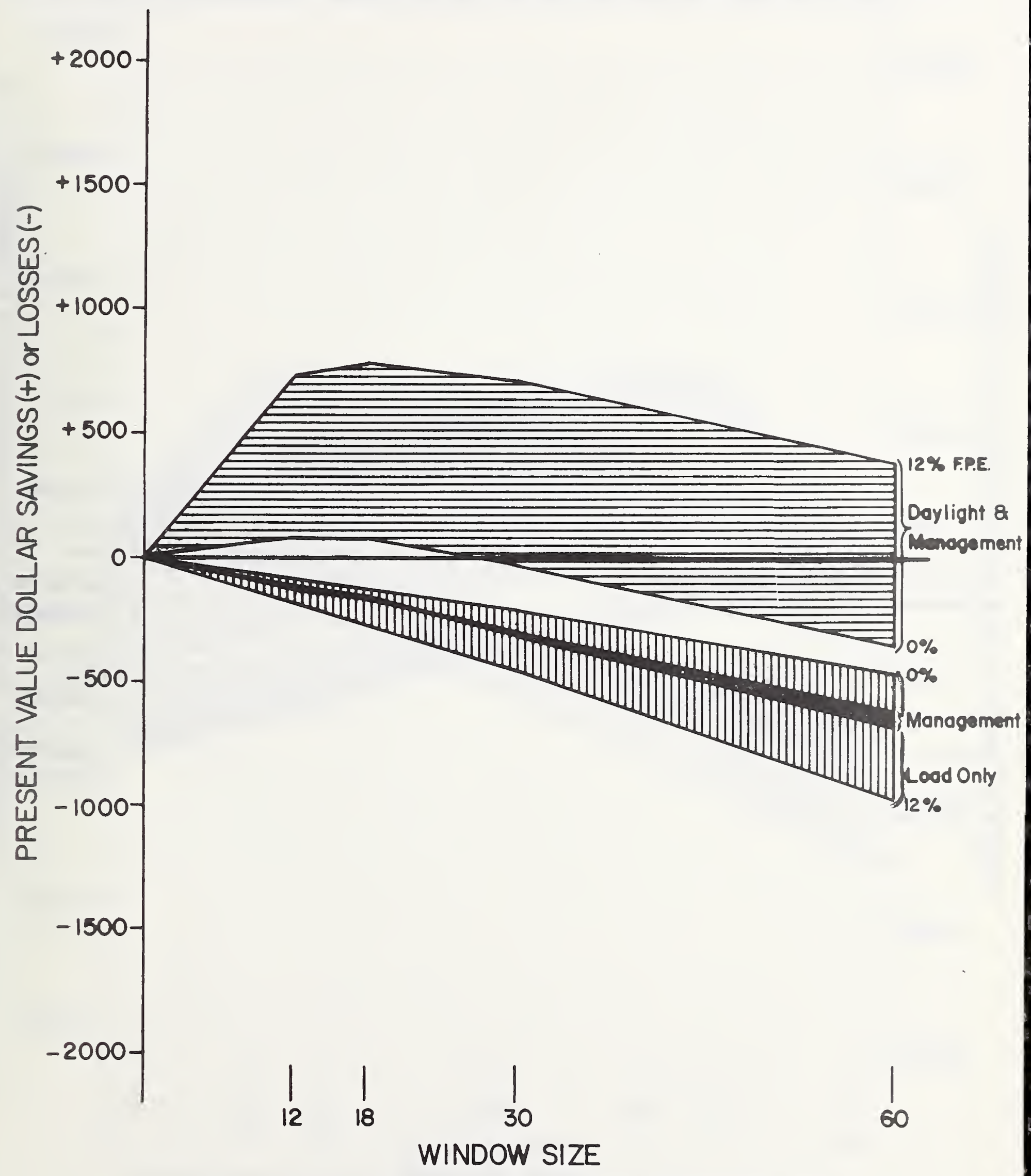


FIGURE 7. SAVINGS OR LOSSES DUE TO A DOUBLE-GLAZED, SOUTH-FACING WINDOW OVER 25 YEARS FOR A RESIDENTIAL MODULE WITH GAS HEATING AND ELECTRIC COOLING - WASHINGTON,D.C. CASE EXAMPLE

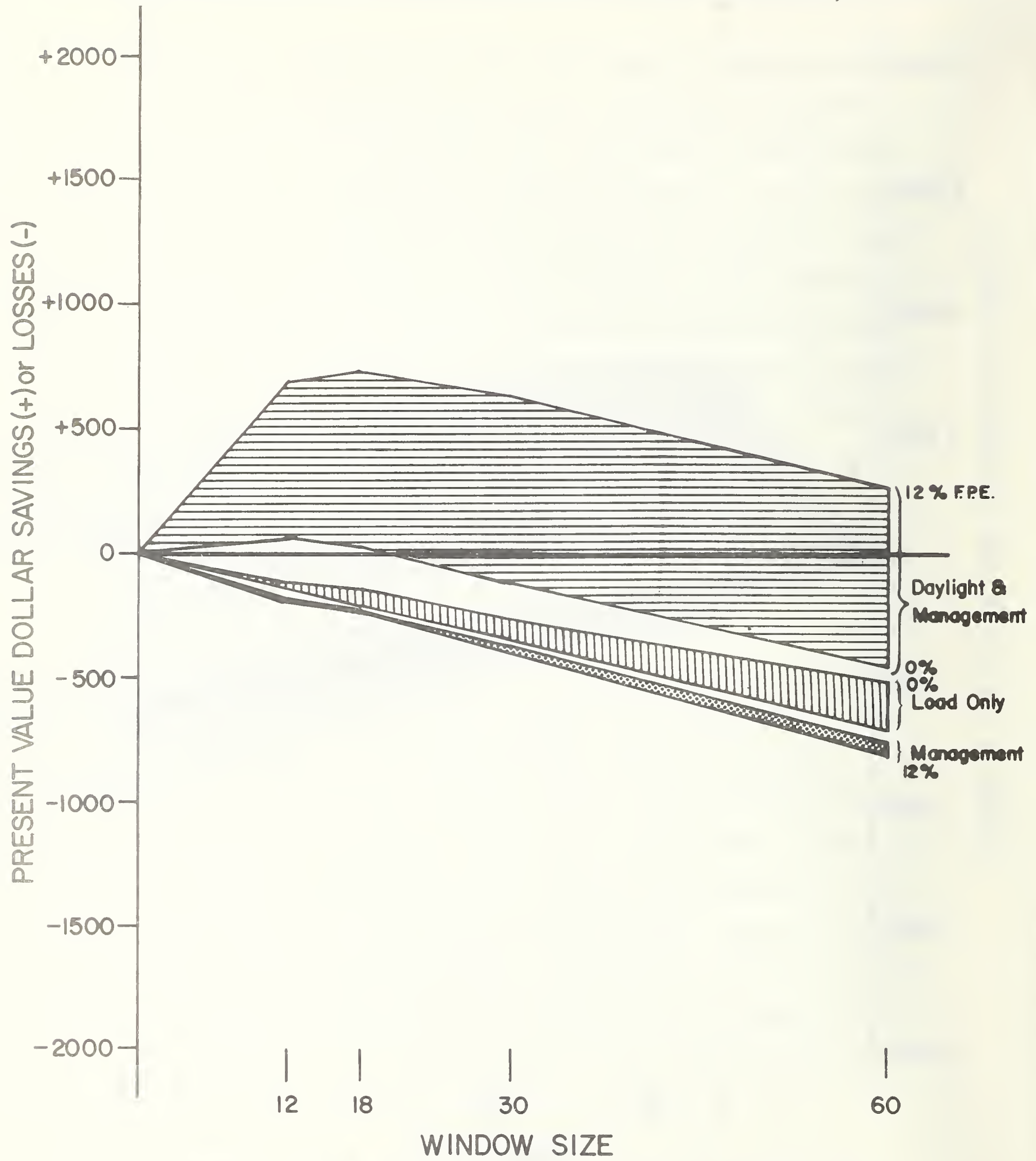
windows beccuss their initial purchase and installation costs ore less. 
FIGURE 8. SAVINGS OR LOSSES DUE TO A SINGLE-GLAZED, NORTH-FACING WINDOW OVER 25 YEARS FOR A RESIDENTIAL MODULE WITH GAS HEATING AND ELECTRIC COOLING - WASHINGTON,D.C. CASE EXAMPLE




FIGURE 9. SAVINGS OR LOSSES DUE TO A DOUBLE-GLAZED, NORTH-FACING WINDOW OVER 25 YEARS FOR A RESIDENTIAL MODULE WITH GAS HEATING AND ELECTRIC COOLING - WASHINGTON,D.C. CASE EXAMPLE

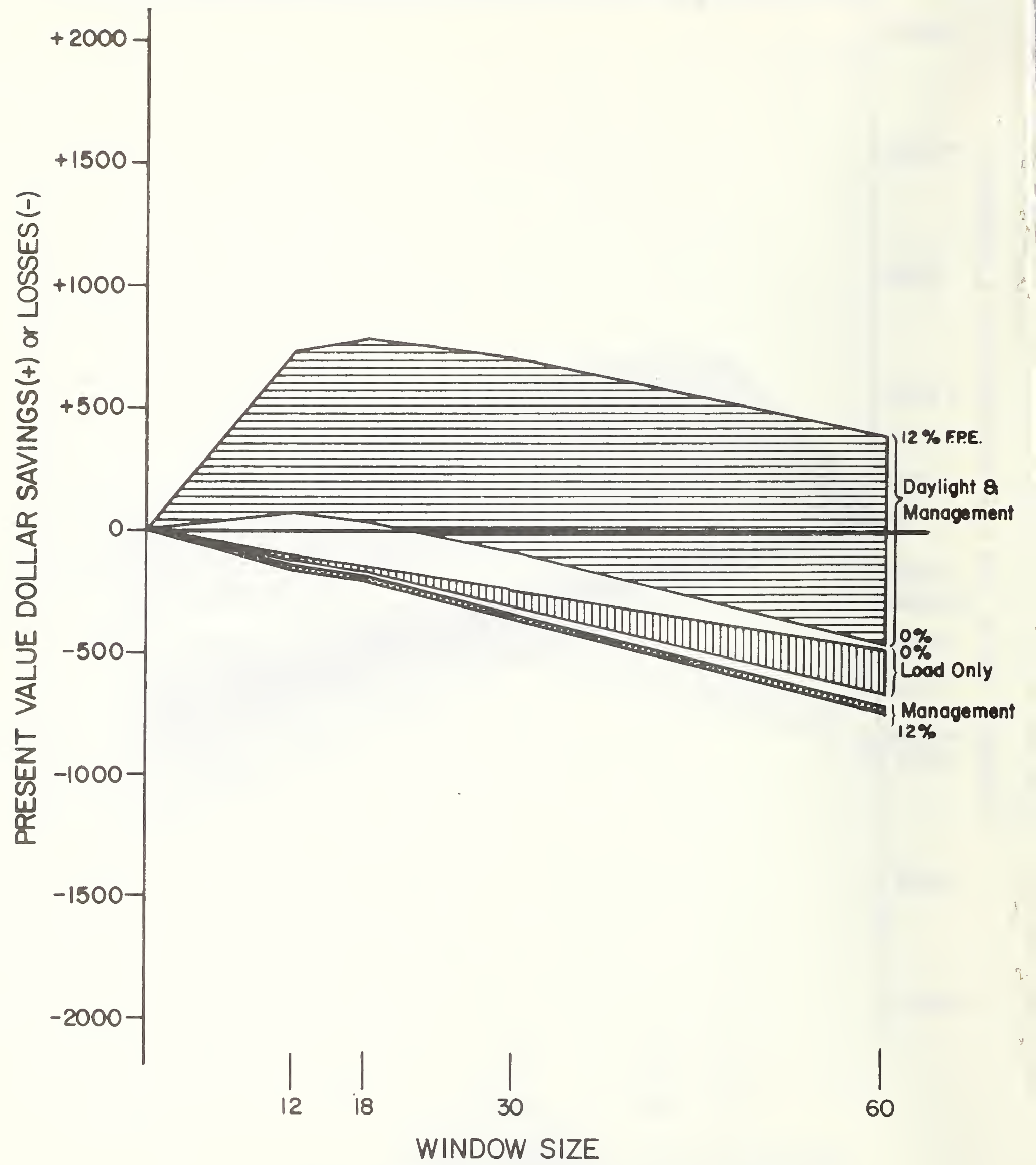


The four figures show that when the potential savings from daylight are excluded, life-cycle costs increase as the window size is increased. With consideration of daylight, net life-cycle savings first rise and then decline as the window size increases, but for the most part remain positive even for large windows.

Beyond this overview, a close examination of the figures is instructive in indicating ways in which the life-cycle costs of windows can be lowered. Looking at the dotted band on Figure 6, we can see that investment in shutters and blinds will of ten tend to pay off for single-glazed windows of all sizes. Looking at Figure 7, we can see that the cost of shutters and blinds will tend not to be recovered in fuel cost savings when used on double-glazed south-facing windows under the conditions indicated. (However, other benefits from shades, blinds, draperies, and shutters, such as privacy, light control, and decorative appeal may make them desirable, together with the energy savings benefit, even if life-cycle cost savings alone do not).

A comparison of Figures 6 and 7 shows that double glazing tends to be cost effective for south-facing windows whose thermal resistance has not already been increased by the use of management devices. The higher the rate of fuel price escalation, the more likely double glazing is to pay off.

Looking now at Figures 8 and 9, we can see that, if energy prices rise sharply, the use of shutters and blinds on north-facing windows is likely to be cost effective in conjunction with single glazing, but is unlikely to be cost effective with double glazing. Comparing Figures 8 and 9, it appears that for moderate to large windowed areas 
on north walls, double glazing would tend to be the most economical choice.

The more expensive the fuel, the more critical the use of smaller window sizes or southern orientations becomes in controlling costs. In addition, higher fuel costs also make management devices or double glazing more worthwhile for both south and north-facing windows.

\subsection{CONCLUSIONS}

It has been demonstrated here that window size, orientation, thermal resistance, management, and daylight can noticeably affect the energy use and life-cycle costs of windows. By determining the cost of energy for the three different levels of analysis, the case example has shown how the energy and overall life-cycle cost effects of windows are influenced by the use of window management, thermostat adjustment, and daylight. The first level of analysis demonstrates that increasing window area, without using either management or daylight, increases heating and cooling costs in a typical home in Washington, D.C. These costs can be reduced, but not eliminated, by using double glazing and orienting windows to the south. The second level of analysis demonstrates that selective window management can be used to reduce further the energy costs associated with increasing area. The third illustration shows that the selective use of daylight as a substitute for electric light may change the energy impact of windows from a negative to a positive one. These findings emphasize the need to verify the potential energy savings attributable to daylight.

The combination of energy costs with acquisition, maintenance, and repair costs over a 25 year period, demonstrates the relationship 
between the energy efficiency and the life-cycle cost efficiency of different window designs. Where energy costs can be reduced with little or no additional investment cost, as by changing orientation from north to south, the least-cost energy decision is also the lowest life-cycle cost decision. However, when capital and labor costs are increased by choosing one window design or accessory over another, these cost increases must be weighed against energy cost savings to determine the most cost-effective decision.

In summary, it is suggested that the following items be considered in the effort to promote the construction and operation of more energyefficient and cost-effective homes:

- Note the direction in which the windows face. Orienting the windows away from the north and away from prevailing winds can cut energy costs substantially.

- Encourage the use of double glazing or storm windows in moderate to cold climates particularly on north walls and for large windows.

- Encourage the use of designs which provide good natural lighting particularly in rooms with predominantly daytime use.

- Encourage the use of window coverings such as draperies, blinds, shades, or shutters, which have good thermal resistance, shading potential, and complement daylight utilization.

- The additional costs incurred in making windows energy-efficient may be offset for the purchaser by psychological benefits such as a view to the outside, sunshine, variety, and enhancement of the interior decor. 


\section{References}

1. Hastings, S. R. and Crenshaw, R. Window Design Strategies to Conserve Energy. BSS 104, U.S. Department of Commerce, NBS, June 1977.

2. Kusuda, T. and Collins, B. L. Simplified Analysis of Thermal and Lighting Characteristics of Windows: Two Case Studies. BSS 109, in press.

3. Ruegg, R. T. and Chapman, R. Economic Evaluation of Windows in Buildings. NBS BSS in preparation.

4. Collins, B. L. Windows and People: A Literature Survey. BSS 70, U.S. Department of Commerce, NBS. June 1975.

5. Holton, J. K. Daylighting of Buildings: A Compendium and Study of Its Introduction and Control. NBSIR 76-1098, October 1976.

6. Chapman, R. Economic Analysis of Experimental Lead Paint Abatement Methods: Phase I. NBS Technical Note 922, September 1976. 
NBS.114A (REV. 7.73)

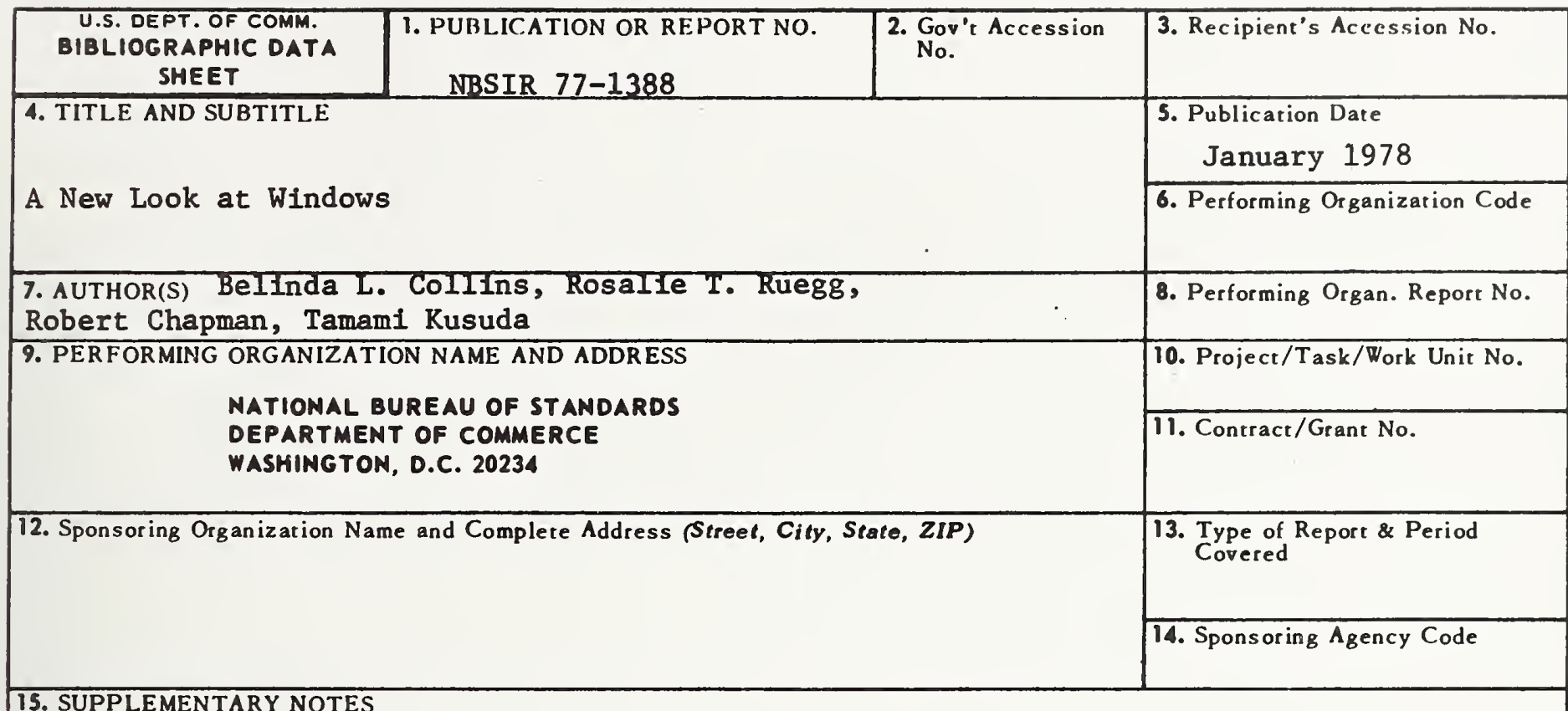

\section{SUPPLEMENTARY NOTES}

16. ABSTRACT (A 200-word or less factual summary of most sicnificant information. If document includes a significant bibliography or literature survey, mention it here.)

Recent design recommendations have called for reduced window area in buildings to conserve energy. This article presents new information on thermal loads, daylighting, management, and life-cycle costs which indicatẹ that such recommendations may neglect important design and operational aspects of windows which can conserve energy resources and reduce life-cycle building costs: A case example is described in which energy consumption and life-cycle costs are given for windows in a typical house in the Washington, D.C. area. Noticeable reductions in overall energy consumption and 1 ifecycle costs are found if daylight is used, and if the window is managed. It is suggested that lending institutions and builders consider the long-term effects of window design and operation decisions.

17. KEY WORDS (six to twelve entries; alphabetical order; capitalize only the first letter of the first key word unless a proper name; separated by semicolons)

Daylighting; energy conservation; life-cycle costs; residential; solar heat gain; window; window management
18. AVAILABILITY
X Unlimited

For Official Distribution. Do Not Release to NTIS

Order From Sup. of Doc., U.S. Government Printing Office

Washington, D.C. 20402, SD Cat. No. C13

X] Order From National Technical Information Service (NTIS) Springfield, Virginia 22151

\begin{tabular}{|l|c|}
\hline $\begin{array}{l}\text { 19. SECURITY CLASS } \\
\text { (THIS REPURT) } \\
\text { UNCL ASSIF IED }\end{array}$ & 21. NO. OF PAGES \\
\hline $\begin{array}{l}\text { 20. SECURITY CLASS } \\
\text { (THIS P AGE) }\end{array}$ & $\begin{array}{l}\text { 22. Price } \\
\text { UNCLASSIFIED }\end{array}$ \\
\hline 4.50 \\
\hline
\end{tabular}


2
2
2
2

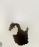


